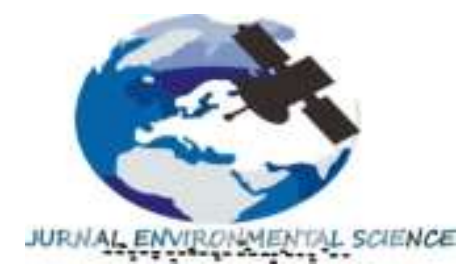

Jurnal Environmental Science

Volume 2 Nomor 1 Oktober 2019

p-ISSN : 2654-4490 dan e-ISSN : 2654-9085

Homepage at : ojs.unm.ac.id/JES

E-mail:jes@unm.ac.id

\title{
ANALISIS POLA PERSEBARAN DAN KETERJANGKAUAN LOKASI SEKOLAH TERHADAP PEMUKIMAN DIKECAMATAN BATAUGA KABUPATEN BUTON SELATAN.
}

\author{
Mukhlis $^{1}$, La Harudu', Rahma Musyawarah ${ }^{3}$ \\ Jurusan Pendidikan Geografi, Fakultas Keguruan Dan Ilmu Pendidikan \\ Universitas Halu Oleo, Indonesia. \\ e-mail:mukhlis19@gmail.com
}

\begin{abstract}
This writing aims to analyze the distribution patterns and find out the affordability of the School's location to the settlements in the Batauga sub-district of South Buton Regency. The method used in this study is a quantitative descriptive method with Nearest Neighbor Analysis and baffer analysis. Data is obtained by survey and document review. The results showed 1) The pattern of distribution of School Locations in Batauga sub-district was calculated using the analysis of the nearest neighbor (Analysis Nearest Nigh) obtained $T$ value $=0.26369$, spatial pattern of School Location distribution in Batauga Subdistrict was Cluster pattern. 2). The results of Spatial Analysis using the Baffer function are the distribution of school locations in Batuaga Subdistrict, which have not fully served all villages in the subdistrict of Batauga. Educational facilities for junior high schools (SMP / MTs) are only able to serve 75\%, namely Lawela Village, Lawela Seatan, Bandar Batauga, Busoa, Lakambau, Majapahit, Pogalampa, Mologina and Bola Village.
\end{abstract}

Keywords: Analysis, Distribution Patterns, Affordability of School Locations, GIS.

\begin{abstract}
ABSTRAK
Penulisan ini bertujuan untuk menganalisa pola persebaran dan mengetahui keterjangkauan lokasi Sekolah terhadap pemukiman dikecamatan Batauga Kabupaten Buton Selatan. Metode yang digunakan dalam penelitian ini adalah metode deskriptif kuantititatif dengan Analisis Neighbour Nearest dan analisis baffer.Data diperoleh dengan survei dan kajian dokumen. Hasil penelitian menunjukan 1) Pola persebaran Lokasi Sekolah di kecamatan Batauga dihitung dengan menggunakan analisis tetangga terdekat (Analysis Nearest Nighbour) diperoleh nilai T=0,26369, pola spasial persebaran Lokasi Sekolah di Kecamatan Batauga adalah tersebar Mengelompok (Cluster pattern). 2). Hasil Analisis Spasial menggunakan fungsi Baffer sebaran lokasi sekolah di Kecamatan Batuaga, sepenuhnya Belum melayani seluruh Desa/Kelurahan yang ada di kecamatan Batauga. Fasilitas pendidikan Sekolah Menengah Pertama (SMP/MTs) hanya mampu melayani 75\% yaitu Desa Lawela, Lawela Seatan, Bandar Batauga, Busoa, Lakambau, Majapahit, Pogalampa, Mologina dan Desa Bola.
\end{abstract}

Kata Kunci: Analisis, Pola Persebaran, Keterjangkauan Lokasi Sekolah, SIG. 


\section{PENDAHULUAN}

Dasar kebijakan pendidikan nasional terkait dengan sebaran dan daya jangkauan pelayanan sekolah dapat di telusuri dari amanat undang-undang nomor 20 tahun 2003 tentang sistem pendidikan. Visi Departemen Pendidikan Nasional adalah Terwujudnya sistem pendidikan sebagai pranata sosial yang kuat dan berwibawa untuk memberdayakan semua warga Negara Indonesia berkembang menjadi manusia yang berkulaitas sehingga mampu dan proaktif menjawab tantangan zaman yang selalu berubah (Zainudin, 2015: 148).

Fasilitas pendidikan yang menjadi prioritas penunjang dalam melengkapi pemenuhan ketersediaan infrastruktur sosial disuatu permukiman yang harus terletak pada posisi yang strategis dan tersebar merata diseluruh daerah (Maesyaroh, 2010). Berdasarkan Standarisasi Nasional (2004), dasar penyediaan sarana pendidikan/sekolah ini juga mempertimbangkan pendekatan desain keruangan unit-unit atau kelompok lingkungan yang ada. Tentunya hal ini dapat terkait dengan bentukan grup bangunan/blok yang nantinya terbentuk sesuai konteks lingkungannya. Sedangkan penempatan penyediaan fasilitas ini akan mempertimbangkan jangkauan radius area layanan terkait dengan kebutuhan dasar sarana yang harus dipenuhi untuk melayani pada area tertentu.

Letak Kecamatan Batauga dilihat dari peta Kabupaten Buton Selatan berada disebelah selatan daerah Pulau Buton.Secara geografis terletak di antara 5,290 - 5,590 LS. Wilayah kecamatan Batauga secara keseluruhan adalah daratan pulau Buton Selatan dengan luas 75,83 km2 dan jumlah penduduk tahun 2016 sebanyak 15.579 jiwa. Secara administrasi kecamatan batauga pada tahun 2016 terdiri dari 12 desa/ (BPS Kecamatan Batauga 2018).

Kecamatan Batauga merupakan ibukota Kabupaten Buton Selatan yang tergolong paling berkembang, ditunjukan dengan aksesibilitas yang bagus, banyak terdapat sekolah dan fasilitas umum/publik yang lengkap serta letaknya yang berbatasan langsung dengan Kota Bau-Bau. Selain itu kemudahan untuk menjangkau akses sarana dan prasarana, kemudahan transportasi dan aksesibilitas menuju pusat kota Bau-Bau, sehingga pemukiman penduduk cenderung memanjang (linear) dengan jalan utama. (Peraturan Menteri pekerjaan Umum No. 41/PRT/M/2007).

Terdapat beberapa ketentuan umum dalam pemanfaatan kawasan permukiman, salah satu diantaranya adalah pemanfaatan dan pengelolaan kawasan permukiman harus didukung oleh ketersediaan utilitas umum (jalan, drainase, air bersih, sanitasi, persampahan, jaringan listrik, dan jaringan telekomunikasi)dan fasilitas umum atau fasilitas penunjang permukiman (kesehatan, pendidikan, peribadatan).

Salah satu fasilitas penunjang permukimam yang sangat dibutuhkan keberadaannya adalah fasilitas pendidikan/sekolah (Pancarrani, 2014: 66). Pembangunan sistem informasi geografi (SIG) merupakan salah satu langkah untuk membantu pemerintah daerah kecamatan Batauga Kabupaten Buton Selatan.Dengan adanya sistem informasi (SIG) sebaran sekolah ini, selain membantu tersedianya sarana informasi bagi pemerintahan di Kecamatan Batauga. Sistem informasi geografi (SIG) juga berguna sebagai media analisa perencanaan dalam proses pembangunan peningkatan 
sarana dan prasarana pendidikan, karena sistem informasi geografi (SIG) mempunyai kemampuan analisis keruangan (spatial analysis) maupun waktu (temporal analysis) sehingga teknologi ini sering dipakai dalam proses perencanaan. Hasil akhirnya diharapkan mampu menjadi sarana informasi masyarakat dan rekomendasi pihak terkait untuk meningkatkan layanan pendidikan di wilayah Kecamatan Batauga. Berdasarkan kepentingan analisis tersebut, peneliti tertarik melakukan penelitian yang berjudul"Analisis Pola Persebaran Dan Keterjangkauan Lokasi Sekolah Terhadap Pemukiman Dengan Menggunakan Sistem Informasi Geografi Kecamatan Batauga Kabupaten Buton Selatan".

\section{METODE PENELITIAN}

Penelitian ini menggunakan penelitian deskriptif kuantitatif dan evaluative untuk mengidentifikasi pola Persebaran spasial dan keterjangkauan lokasi Sekolah terhadap pemukiman di wilayah Kecamatan Batauga, Kabupaten Buton Selatan.

\section{Populasi dan Sampel}

\section{Populasi}

Populasi adalah wilayah generalisasi yang terdiri atas obyek atau subyek yang mempunyai kualitas dan karakteristik tertentu yang ditetapkan oleh peneliti untuk dipelajari dan kemudian ditarik kesimpulanya (Sugiyono, 2012). Populasi dalam penelitian ini adalah seluruh fasilitas pendidikan yang berjumlah 42 Sekolah dari jenjang pendidikan Pra Sekolah (Taman Kanak-Kanak), Sekolah Dasar (SD), Sekolah Lanjutan Tingkat Pertama (SLTP), dan Sekolah Lanjutan Tingkat Atas (SLTA) di Kecamatan Batauga Kabupaten Buton Selatan.

\section{Sampel}

Metode yang digunakan dalam penarikan sampel ini adalah sampling jenuh atau sensus. Menurut Sugiyono 2008 dalam Nyoman (2010), Sampling jenuh atau sensus adalah teknik penentuan sampel bila semua anggota populasi digunakan sebagai sampel. Istilah lain sampling jenuh adalah sensus.

\section{Lokasi Penelitian}

Penelitian ini dilaksanakan di Kecamatan Batauga, Kabupaten Buton Selatan, dan berlangsung dari bulan Januari sampai selesai. 
Gambar 3.1. Peta Administrasi Kecamatan Batauga, Kabupaten Buton Selatan

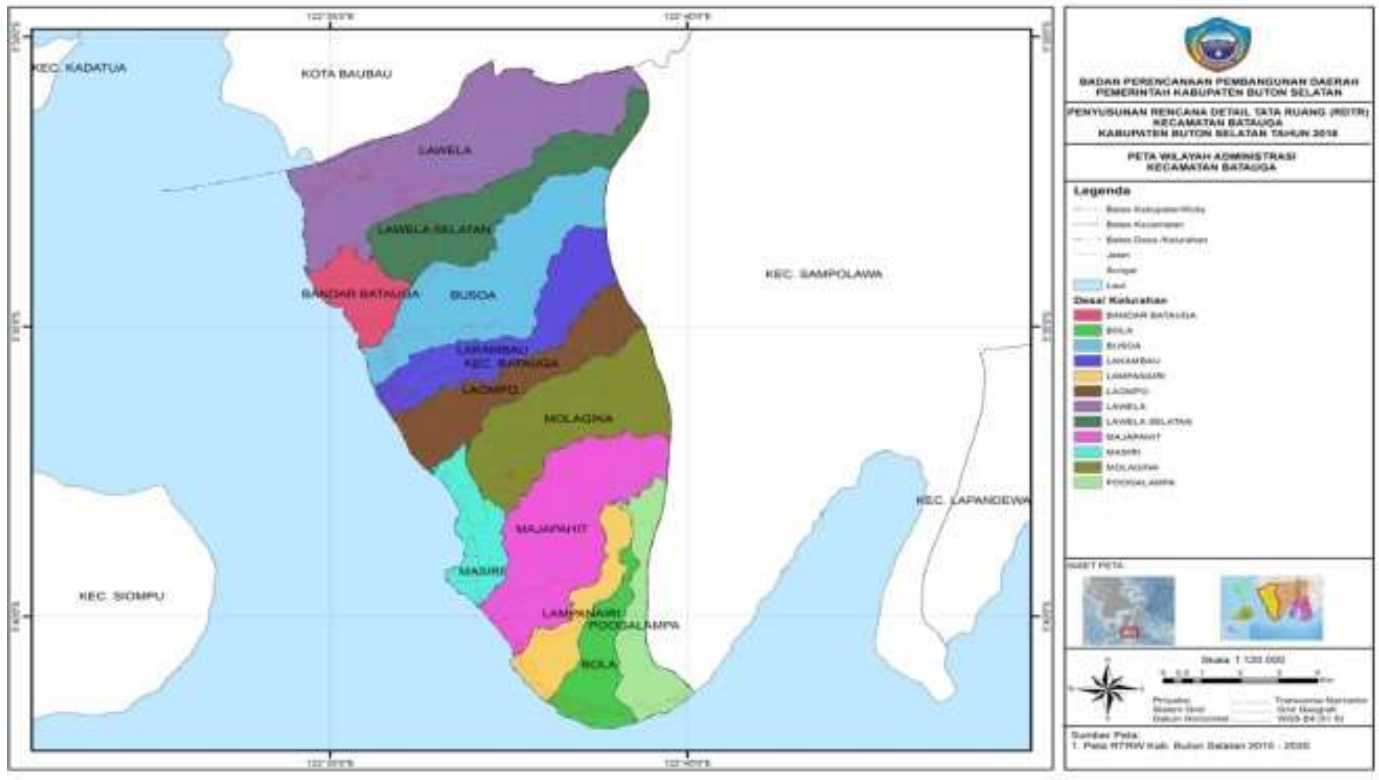

Sumber: BAPPEDA Buton Selatan 2016

\section{Jenis Data dan Sumber Data}

Survei dan pemetaan yang digunakan dalam survei dan pemetaan ini adalah jenis data spasial dan data atribut.

\section{Data Spasial}

Data Spasial merupakan data yang memiliki refrensi ruang kebumian (georefrece) dimana terdapat berbagai data atribut terletak dalam berbagai unit spasial. Data spasial yang digunakan dalam penelitian adalah Peta Administras kecamatan Batauga sumber BAPPEDA atau Instansi terkait.

2. Data Atribut

Data Atribut biasa disebut juga elemen, data field atau item yang digunakan untuk menerangkan suatu identitas. Data Atribut yang digunakan dalam penelitian ini adalah: Data Penduduk Kecamatan Batauga, untuk mengetahui informasi umum lokasi survei dan pemetaan seperti letak geografis, banyaknya jumlah penduduk dikecamatan batauga, banyaknya jumlah Pendidikan formal.

\section{Metode Pengumpulan Data.}

1. Sumber Data Primer

a. Observasi

Observasi dilakukan dengan pengamatan langsung dilapangan yaitu seluruh unit Sekolah.Kegiatan ini bermaksud untuk melihat keadaan kenampakn lokasi sekolah dengan pemberian titik tersebut menggunakan bantuan Global Posisition System (GPS).yang kemudian dilakukan ploting saat observasi dilapangan, hasil yang diperoleh dari GPS akan dilakukan 
pengelolaan dengan menggunakan software ArcGis 10.3 untuk memperoleh peta pola sebaran dan radius keterjangkauan fasilitas pendidikan/Sekolah.

2. Sumber data sekunder

Data yang diambil dari buku-buku, dokumentasi, dan literatur literatur, meliputi :

a. Studi Kepustakaan

Pengumpulan data dari buku-buku yang sesuai dengan tema permasalahan, yaitu buku-buku yang ada dan data-data dari pemerintahan kecamatan, Badan Perencanaan Pembangunan Daerah, buku Geografi tentang Pemetaan.

b. Studi Dokumentasi

Pengumpulan data dari literatur-literatur dan dokumentasi dari Internet, Goole Eart, SAS Planet, dan sumber informasi lain,misalnya ; gambar-gambar denah dan peta. Pengumpulan data penelitian menggunakan kelaziman umum penelitian kualitatif, yang terdiri dari teknik pengumpulan data melalui observasi lapangan, wawancara, dan dokumentasi.

\section{Metode Analisis Data}

\section{Arc Gis.10.3}

Metode pengolahan data pada penyususnan Tugas Akhir ini dilakuakan dengan perangkat lunak ArcGis.10.3merupakan perangkat lunak Geography Information System yang sangat popular dan paling banyak digunakan untuk mengelola data spasial sehingga data tersebut dianalisis dan dibuat peta serta laporan yang berkaitan dengan data spasial bereferensi geografis sehingga dihasilkan project, view, tabel, chart, layout dan script (Animsa, 2015).

\section{Analisis Tetangga Terdekat (Nearest Neighbour Analysis)}

Analisis tetangga terdekat merupakan salah satu analisis yang digunakan untuk menjelaskan pola persebaran dari titik-titik lokasi tempat dengan menggunakan perhitungan yang mempertimbangkan, jarak, jumlah titik lokasi dan luas wilayahdengan rumus yang digunakan dalam NNA (Nearest Nearest Neighbour Analysis) adalah sebagai berikut:

$$
\begin{gathered}
T=\frac{J u}{J h} \\
J u=\frac{\text { jumlah jarak }}{\text { jumlah titik }} \\
J h=\frac{1}{2 \sqrt{P}} \\
P=\frac{\text { jumlah titik }}{\text { luas wilayah }}
\end{gathered}
$$


Keterangan:

$\mathrm{T} \quad=$ Indeks Penyebaran tetangga terdekat.

$\mathrm{Ju}=$ Jarak rata-rata yang diukur antara suatu titik dengan tetangga terdekat.

$\mathrm{Jh}=$ Jarak rata-rata yang diperoleh andaikata semua titik mempunyai pola random.

\section{Buffer}

Buffer merupakan bentuk lain dari teknik analisis yang mengidentifikasi hubungan antara suatu titik dengan area di sekitarnya atau disebut sebagai Proximity Analysis (analisis faktor kedekatan). Proximity Analysis merupakan proses analisa yang biasa digunakan dalam penentuan site/lahan untuk keperluan strategi (Aqli, 2010: 195).

\section{HASIL DAN PEMBAHASAN}

\section{Analisis Pola Persebaran Lokasi Sekolah}

Pola persebaran lokasi sekolah dimaksudkan untuk menjelaskan secara keruangan persebaran seluruh sekolah di Kecamatan Batauga, Kabupaten Buton Selatan yang mengacu pada peta sebaran lokasi sekolah. Dalam analisis pola persebaran lokasi sekolah menggunakan analisis tetangga terdekat (nearest neighbour analysis), perlunya melakukan pemetaan lokasi-lokasi sekolah dengan bantuan Global Positioning System (GPS) untuk penentuan Kordinat tiap lokasi sekolah di kecamata Batauga.

\section{Peta Persebaran Lokasi Sekolah Kecamatan Batauga Kabupaten Buton Selatan}

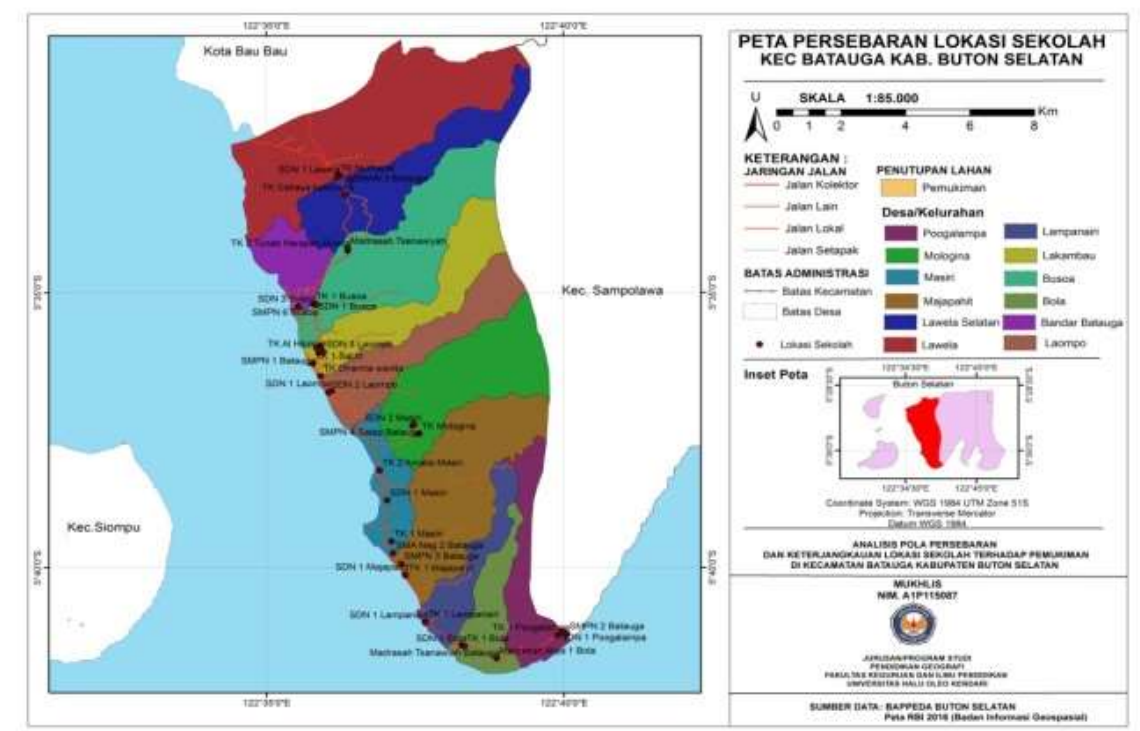

Sumber: Olahan ArcGis 10.3 
Dari data dapat diketahui bahwa jumlah jarak dalam Km 8,313 Sedangkan luas wilayah Kecamatan Batauga 94,69 $\mathrm{Km}^{2}$ Sehingga perhitungan $\mathrm{T}$ adalah sebagai berikut :

1. Ju $=\frac{\text { Jumlah Jarak }}{\text { Jumlah Titik }}=\frac{8,313}{42}=0,197928$

2. $\quad P=\frac{\text { Jumlah Titik }}{\text { Luas Wilayah }}=\frac{42}{94,69}=0,443552$

3. $\mathrm{Jh}=\frac{1}{2 \sqrt{\mathrm{P}}}$

$$
\begin{aligned}
& =\frac{1}{2 \sqrt{0,443552}} \\
& =\frac{1}{2 \cdot 0,665996} \\
& =\frac{1}{1,331992}=0,7507525
\end{aligned}
$$

4. $T=\frac{J u}{J h}=\frac{0,197928}{0,7507525}$

$$
=0,26369
$$

Berdasarkan hasil perhitungan diatas menunjukan bahwa niali $\mathrm{T}$ persebaran lokasi sekolah di kecamatan Batauga, Kabupaten Buton Selatan adalah sebesar 0,26369. Hal ini menandakan bahwa pola perebaran lokasi sekolah di Kecamatan Batauga Kabupaten Buton Selatan adalah tersebar secara mengelompok (cluster pattern) karena mempunyai nilai $\mathrm{T}<1$.

1. Analisis Jarak Jangkauan Lokasi Sekolah Terhadap Pemukiman.

Berdasarkan pengamatan dilapangan dan hasil olahan spasial Baffer menggunakan Software ArcGis 10.3 ketersediaan Taman Kanak-Kanak di kecamatan Batauga terdiri atas 15 Unit tersebar dibeberapa Desa/Kelurahan yang berlokasi berdampingan dengan SD (Sekolah Dasar) ditengah pemukiman. Berdasarkan hasil analisisspasial dengan menggunakan fungsi buffer, seluruh wilayah desa di Kecamatan Batauga sudahterlayani fasilitas pendidikan sekolah Taman Kanak-Kanak.

2. Jangkauan Pelayanan Berdasarkanstandar Nasional Indonesia 13-1733-2004, pendidikan Sekolah Dasar memiliki radius jangkauan pelayanan dengan radius jangkauan sejauh 1000 meter $^{2}$. Kecamatan Batauga memiliki 13 fasilitas pendidikan SD (Sekolah Dasar) yang tersebar di seluruh Desa/Kelurahanhanya Desa Lawela Selatan belum tersedia fasilitas SD (Sekolah Dasar) namun telah terlayani oleh Fasilitas Sekolah SD dari Desa Lawela, karena masih terkena Radius Baffer Pelayanan di Kecamatan Batauga.

3. Hasil analisa data berdasarkan Analisis Baffer menunjukkan bahwa SMP/MTs yang terdiri dari 8 unit Fasilitas Pendidikan/Sekolah hanya mampu melayani 9 Desa/kelurahan sedangkan 3 Desa/kelurahan lainya belum terlayani. Hal ini berdasarkan Analisis Baffer besaran keterimaan pelayanan sekolah terhadap pemukiman ditiap Desa/Kelurahan yang ada di Kecamatan Batauga. Fasilitas Pendidikan/Sekolah SMP/MTs telah mampu melayani 9 Desa/Kelurahan sedangkan 3 
Desa/kelurahan yang belum terkena dampak radius baffer layanan sekolah terhadap pemukiman

Desa/Kelurahan di Kecamatan Batauga. Apabila dipresentasekan Fasilitas Pendidikan/Sekolah hanya dapat melayani 75 \% Desa/Kelurahan di kecamatan Batauga, Kabupaten Buton Selatann.

Persentase $=\frac{\sum \text { skordata yang diperoleh }}{\sum \text { skortotal }} \times 100 \%$

(Sumber :Ali, 1993 dalam Abidin 2015)

$$
\begin{aligned}
& =\frac{\text { Desa } / \text { Kelurahan yang Terlayani }}{\text { JumlahKeseluruhanDesa } / \text { Kelurahan }} \times 100 \% \\
& =\frac{9}{12} \times 100=75 \%
\end{aligned}
$$

4. Berdasarkan atas keterjangkauanya terhadap pemukiman menunjukkan bahwa SMA yang terdiri dari 6 unit Fasilitas Pendidikan/ Sekolah telah mampu melayani hampir seluruh Desa/Kelurahan di kecamatan Batauga hanya Desa/kelurahan Mologina,yang belum terkena dampak radius baffer layanan sekolah SMA terhadap pemukiman. Sehingga apabila dipresentasekan Fasilitas Pendidikan/Sekolah Menengah Atas hanya dapat melayani 91,6\% Desa/Kelurahan di kecamatan Batauga, Kabupaten Buton Selatann.

Persentase $=\frac{\sum \text { skor datay ang diperoleh }}{\sum \text { skortotal }} \times 100 \%$

(Sumber :Ali, 1993 dalam Abidin, 2015)

$$
\begin{aligned}
& =\frac{\text { Desa } / \text { Kelurahan yang Terlayani }}{\text { JumlahKeseluruhanDesa } / \text { Kelurahan }} \times 100 \% \\
& =\frac{11}{12} \times 100=91,6 \%
\end{aligned}
$$

\section{Pembahasan}

\section{Pola Persebaran Lokasi sekolah di Kecamatan Batauga}

Analisis spasial dengan pendekatan pola persebaran spasial menjadi aspek penting dalam penentuan pola spasial secara kuantitatif. Pengukuran menggunakan pendekatan kuantitatif dengan berbantuan Sistem Informasi Geografis (SIG), dalam hal ini adalah Aplikasi ArcGis10.3 dapat dilakukan dengan analisis statistik berbasis jarak atau dapat disebut dengan analisis pola berbasis jarak. Metode yang digunakan dalam teknik ini yaitu analisis tetangga terdekat (Nearest Neighbor Analysis). Berdasarkan Penelitan yang dilakuakan dengan Analisis NNA, (Nearest Neighbor Analysis) dengan bantuan software ArcGis 10.3. menunjukkan pola distribusi/persebaran spasial Lokasi Sekolah di Kecamatan Batauga dikategorikan kedalam pola mengelompok. Hasil analisis tetangga terdekat menunjukkan bahwa Sekolah di Kecamatan Batauga, dengan 38 titik dengan nilai $\mathrm{T}=$ 0,26369 yang artinya menunjukkan pola Persebaran Lokasi Sekolah mengelompok (cluster pattern) karena mempunyai nilai $\mathrm{T}<1$. 


\section{Keterjangkauan Lokasi Sekolah Terhadap Pemukiman di Kecamatan Batauga}

Faktor eksternal keterjangkauan pelayanan fasilitas pendidikan adalah data hasil intersect buffering jangkauan pelayanan dari tiap tiap sekolah yang tersedia di kecamatan Batauga. Membuat buffer sesuai jarak yang sudah ditentukan pada tabel 2.2 SNI 13-1733-2004.Buffer dilakukan pada tiap-tiap Fasilitas Pendidikan/Sekolah disetiap jenjang. Dengan cara pilih "ArcToolbox" $\rightarrow$ AnalysisTools $\rightarrow$ Proximity $\rightarrow$ MultipleRing Buffer $\rightarrow$ ditampilkan kotak dialog Multiple Ring Buffer memasukan pada kolom input feature dengan file Jenjang Sekolah yang sudah disimpan. Setelah itu mengisi pada kolom output feature class dengan nama dan direktori penyimpanan hasil multi ring buffer. Kemudian masukan jarak-jarak yang ditentukan sesuai dengan SNI 13-1733-2004 pilih $\rightarrow$ OK.

Hasil buffer jangkauan layanan sekolah dalam menganalisa faktor eksternal (sekolah yang terkena dampak radius layanan sekolah terhadap pemukiman di kelurahan lain). Faktor eksternal yang dimaksud adalah besaran keterimaan pelayanan sekolah dari luar, sehingga keterjangkauan yang dimaksud adalah melihat pemukiman ditiap kelurahan yang terjangkau oleh sekolah-sekolah yang ada di kecamatan Batauga. Sehingga dapat dikatakan pemukiman warga yang berada di dalam jangkauan pelayanan baffer tersebut yang berdasarkan standar Nasional Indonesia 13-1733-2004, merupakan daerah yang sudah terlayani fasilitas pendidikan Sekolah.

Berdasarkan analisis spasial Buffering Keterjangkauan Taman Kanak-Kanak (TK) telah melayani seluruh Desa/Keluarahan yang ada di Kecamatan Batauga.Bisa dilihat dari Lokasi Sekolah TK dan SD tersebar hampir di setiap Desa/Kelurahan dan masih berada pada dalam radius jangkauan pelayanan sekolah di Kecamatan Batauga Kabupaten Buton Selatan.Sementara SMP/MTs dikecamatan Batauga hanya $75 \%$ melayani setiap pemukiman dimasing masing Desa/Kelurahan. Desa/Kelurahan yang belum terlayani dan terjangkau SMP/MTs yaitu Desa masiri, Desa Laompo dan Desa Lampanairi yang belum terjangkau, karena berada diluar radius jangkauan pelayanan sekolah. Sementar SMA/SLTA sederajat memiliki radius jangkauan pelayanan tertentu dengan radius jangkauan sejauh 3000 meter. Kecamatan Batauga memiliki 6 fasilitas pendidikan Sekolah Menengah Atas yang tersebar di empat desa yakni untuk SMAN 1 Batauga dan SMK Al Safitri berloksi di Desa Lakambau, SMAN 2 Batauga, berlokasi di Desa Masiri, Sementara Madrasah Aliya 1 berlokasi di Desa Bola sedangkan SMK Negeri 1 Batauga, berlokasi di Desa Poogalampa dan SMAN 3 Batauga berlokasi di Desa Lawela Selatan. Keempat fasilitas pendidikan tersebut harus menjangkau 12 wilayah Desa/Kelurahan yang ada di Kecamatan Batauga. Berdasarkan hasil analisis spasial dengan menggunakan fungsi buffer, seluruh wilayah desa di Kecamatan Batauga sudah 91,6\% terlayani oleh fasilitas pendidikan SMA/SLTA (Sekolah Menengah Atas). Adapun pemukiman Desa yang belum terlayani Fasilitas Pendidikan Sekolah SMA/SLTA adalah Desa Mologina (berada di luar radius jangkauan pelayanan Fasilitas Pendidikan Sekolah). 


\section{SIMPULAN DAN SARAN}

Berdasarkan hasil Analisis Spasial menggunakan fungsi Baffer sebaran lokasi sekolah di Kecamatan Batuaga, sepenuhnya Belum melayani seluruh Desa/Kelurahan yang ada di kecamatan Batauga. Fasilitas pendidikan Sekolah Menengah Pertama (SMP/MTs) hanya mampu melayani 75\% yaitu Desa Lawela, Lawela Seatan, Bandar Batauga, Busoa, Lakambau, Majapahit, Pogalampa, Mologina dan Desa Bola. Sedangkan Desa/Kelurahan yang belum terlayani Fasilitas pendidikan Sekolah Menengah Pertama (SMP/MTs) yaitu Desa Masiri, Desa Laompo dan Desa Lampanairi. Sementara untuk Sekolah Menengah Atas (SMA) telah 91,6\% telah melayani keseluruhan Desa/Kelurahan di Kecamatan Batuga, Adapun yang belum terjangkau oleh fasilitas pendidikan Sekolah Menengah Atas (SMA) adalah Desa Mologina. Saran terkait untuk pemerintah Kecamatan Batauga Buton Selatan, Kesesuain lokasi gedung sekolah meskipun tidak menjadi masalah bagi penduduk untuk bersekolah di sekolah tersebut, tapi sebaiknya pembangunan sekolah didirikan pada tempat yang dianggap sesuai pada lokasi yang akan dibangun sekolah. Hal ini agar memudahkan penduduk untuk menuju ke sekolah tersebut. Penambahan sekolah SMP/MTs dan SMA di Kecamatan Batauga Sangat dibutuhkan untuk memenuhi kebutuhan penduduk usia sekolah di Kecamatan Batauga Kabupaten Buton Selatan. Penambahan Sekolah di Kecamatan Batauga harus memperhatikan lokasi yang tepat guna menghindari penumpukan pelayanan sehingga dapat menjangkau seluruh Desa/Kelurahan di Kecamatan Batauga Kabupaten Buton Selatan.

\section{DAFTAR RUJUKAN}

Animsa,D.R dan Aeri Rachmad. 2015. Aplikasi Pemetaan Kantor Dinas Di Kabupaten BangkalanMadura Berbasis Android. Jurnal Sistem Informasi. Vol 2(2):24.

Aqli Wafirul. 2014. Analisa Buffer Dalam Sistem Informasi Geografis Untuk Perencanaan Ruang Kawasan. Jurnal Inersia. Vol Vl (2): 195.

BPSKecamatan Batauga.2018. BPS Kecamatan Batauga Dalam Angka 2018. Buton Selatan

Maesyaroh,.S. 2010. Implementasi Algoritma Topsis Dalam Pemelihan Dan Penentuan Kompetensi Asisten Laboratorium Di Fkom Uniku. Jurnal Buffer Informatika.Vol 4(1), 2010.

Pancarrani, G.P., dan Pigawati,B. 2014. Evaluasi Kesesuaian Lokasi Dan Jangkauan Pelayanan

Sekolah Menengah Umum di Kecamatan Kebakkramat Kabupaten Karanganyar. Jurnal Geoplanning. Vol.1 (2):66.

Undang-Undang Negara Kesatuan Republik Indonesia No. 20 tahun 2003 tentang sistem pendidikan nasional.2003 : Republik Indonesia

Zainudin, M. 2015. Daya jangkau Siswa Ke SMP Negeri 1 Padangan Kabupaten Bonjonegoro Provinsi Jawa Timur.Jurnal geografi dan Pengajaran. Vol 13(2): 148. 